\title{
Tamm-Horsfall protein in the glomerular capsular space
}

\author{
A. R. McGiven, J. S. HUNT, W. A. DAY, AND R. R. BAIleY \\ From the Department of Pathology, University of Otago, Christchurch Clinical School of Medicine and \\ the Department of Renal Medicine, Christchurch Hospital, Christchurch, New Zealand
}

SUMMARY Tamm-Horsfall protein was detected within the capsular space by immunofluorescence in 7 of 72 consecutive patients on whom renal immunopathological studies were performed. Three $\stackrel{\omega}{-}$ patients showed prominent aggregates or crescentic collections affecting 30-50\% glomeruli; the 2 remaining four patients showed smaller aggregates between lobules. All patients showed pathological N evidence of tubulointerstitial disease. It is suggested that Tamm-Horsfall protein in the capsular 윽 space is a sign of intratubular urinary backflow and that Tamm-Horsfall antiserum is a useful addition to the reagents used in the immunofluorescence study of renal biopsies.

Tamm-Horsfall protein (THP) is a urinary glycoprotein secreted by the renal tubular cells of the ascending loop of Henle and distal convoluted tubule (McKenzie and McQueen, 1969; Schenk et al., 1971; Wallace and Nairn, 1971). It has a molecular weight of $7 \times 10^{6}$ daltons, composed of subunits each of approximately $10^{5}$ daltons (Fletcher et al., 1970) and is a prominent component in tubular casts (McQueen, 1962). We report here the demonstration of THP in the capsular space in seven patients, who had had renal immunopathological examinations during the past year at the Christchurch Hospital, and conclude that this indicates evidence of renal tubular backflow associated with tubulo-interstitial damage.

\section{Methods}

Specimens from patients $1,4,5$, and 6 were needle biopsies. An open biopsy was obtained during the removal of an adrenal tumour from patient 2 , and transplanted kidneys were obtained from patient 3 at necropsy and from patient 7 at operation. The tissue was examined by conventional histology, immunofluorescence, and electron microscopy.

\section{HISTOLOGY}

Tissue blocks were fixed in formalin and examined after staining by haematoxylin and eosin, periodic acid Schiff, methenamine silver, and Masson trichrome methods.

Received for publication 1 December 1977
IMMUNOFLUORESCENCE

Blocks were stored at $-70^{\circ} \mathrm{C}$ and $4 \mu \mathrm{m}$ sections were cut in a cryostat at $-20^{\circ} \mathrm{C}$. All fluorescence staining was carried out by placing one drop of a 1:5 dilution of conjugated antisera on frozen sections of renal tissue for 30 minutes, followed by two 5 -minute $\frac{\mathrm{Q}}{\mathbb{D}}$ washes in phosphate buffered saline (pH 7.2). In addition to specific antisera for immunoglobulins, albumin, fibrin, and complement components, antiserum against Tamm-Horsfall glycoprotein was used.

THP was isolated from pooled human urine by precipitation with $0.58 \mathrm{M} \mathrm{NaCl}$. Anti-THP serum $\dot{0}$ was prepared by injecting New Zealand white rabbits subcutaneously with $1 \mathrm{mg}$ THP at multiple sites on $\delta$ two occasions at intervals of four weeks. Rabbits were bled from an ear vein one week later. Rabbit o antihuman THP was purified by passing a $10 \mathrm{ml}$ sample of immune serum through a $1.0 \times 3.5 \mathrm{~cm}$ 을 column of THP linked to cyanogen bromide activated Sepharose 4B (Pharmacia, Sweden) and eluting o the bound immunoglobulin with $0.2 \mathrm{M}$ glycine $\mathrm{HCl}$, N pH 2.0. This fraction, which showed a single line $\mathrm{W}_{\mathrm{N}}$ against THP on immunodiffusion, was conjugated 0 to fluorescein isothiocyanate (Nairn, 1976) and un- 0 conjugated dye was removed by chromatography on $\frac{0}{\Phi}$ Sephadex G25 using phosphate buffered saline as $\stackrel{\oplus}{\rightarrow}$ eluate. The conjugated antiserum was concentrated 0 to $6 \mathrm{ml}$ and stored at $-20^{\circ} \mathrm{C}$.

In control studies, a 1:20 dilution of anti-THP serum was absorbed with an equal volume of THP $\mathbb{\Phi}$ $(1 \mathrm{mg} / \mathrm{ml})$ at $37^{\circ} \mathrm{C}$ for one hour and centrifuged, and $\frac{2}{\sigma}$ the supernatant was used on sections staining for 
THP. Positive staining was abolished in absorbed serum but persisted in sections stained with the equivalent concentration of unabsorbed serum.

\section{ELECTRON MICROSCOPY}

Ultrathin sections prepared from glutaraldehydefixed tissue embedded in Spurr's resin were examined after staining with lead citrate (McGiven et al., 1977).

\section{Results}

Seven of 72 renal biopsies studied for the presence of Tamm-Horsfall protein revealed THP within the glomerular capsular space in addition to the usual localisation in the ascending limb of the loop of Henle, distal tubules, and casts. The quantity of THP varied from occasional small droplets between glomerular lobules to larger aggregates (Figs 1 and 2), peripheral droplets often confluent and adherent to the parietal epithelial cells (Fig. 3), and prominent crescentic accumulations, which almost filled the capsular space in the most advanced cases (Fig. 4).

The patients' ages ranged from 20 to 49 years, and the clinical diagnoses and immunopathological findings are summarised in the Table. Three patients showing the greatest accumulation of THP in the capsular space are considered in more detail:

\section{Case 1}

A man of 36 years presented with hypertension and renal failure for investigation. He had recently suffered from a prostatic abscess.
HISTOLOGY

The glomeruli showed a mild increase in the mesangium, and the capsular space, which was prominent, frequently contained remnants of proteinaceous material (Fig. 5). Some tubules were dilated and there was marked tubular degeneration with proteinaceous material, inflammatory and epithelial cells, and erythrocytes in the lumen of several tubules. The interstitium showed oedema and

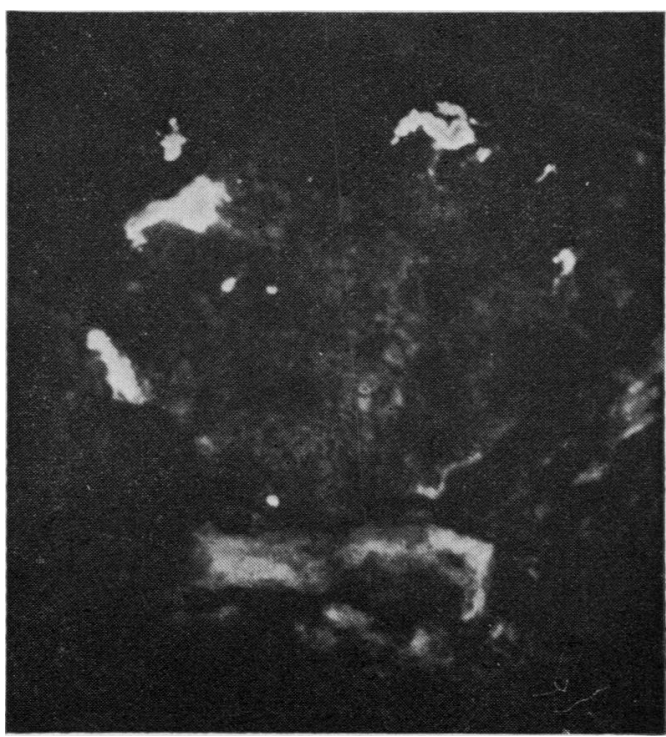

Fig. 1 Patchy aggregates of Tamm-Horsfall protein in capsular space (case 6). $\times 150$

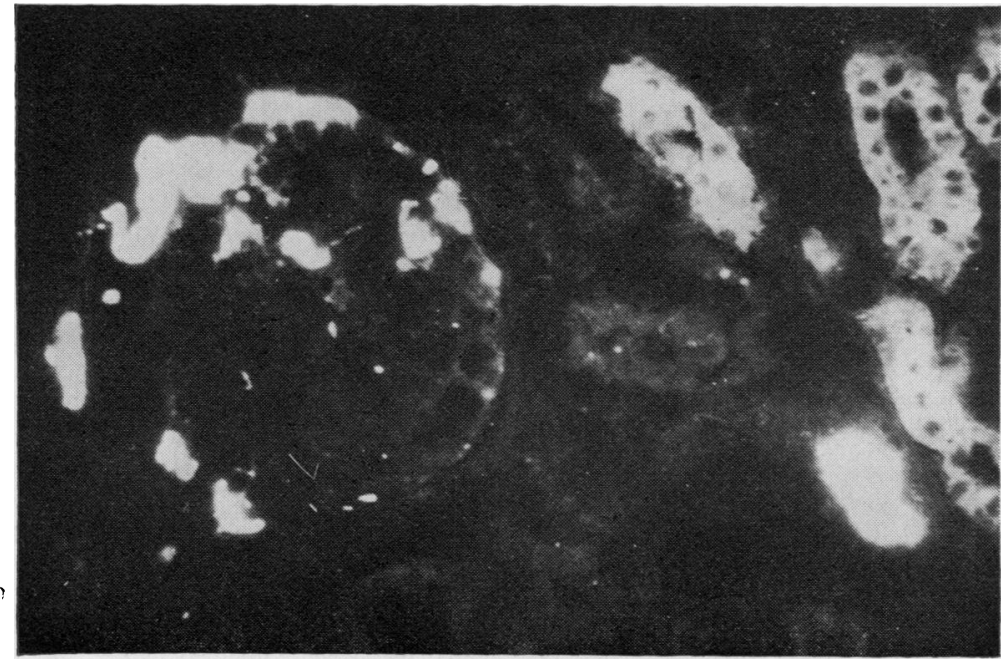

Fig. 2 Tamm-Horsfall protein stains brightly in tubular cast as well as in distal convoluted tubules. Prominent aggregates in capsular space and between glomerular loops (case 7). $\times 150$. 
Renal immunopathological information in seven patients with glomerular Tamm-Horsfall protein

Fig. 3 Tamm-Horsfall protein adheres to parietal capsular epithelial lining. Occasional interlobular aggregates (case 7). $\times 150$

Fig. 4 Prominent crescentic Tamm-Horsfall protein aggregate in capsular space (case 1$). \times 150$

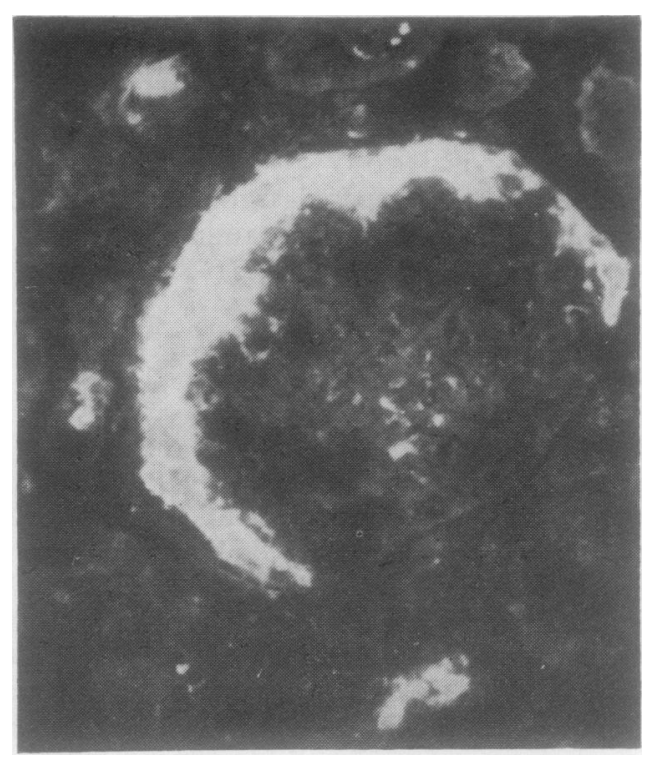

\begin{tabular}{|c|c|c|c|c|c|c|}
\hline Case & $\operatorname{Sex}$ & Age & Diagnosis & Histology & Immunofluorescence & Glomerular THP immunofluorescence \\
\hline 1 & $\mathbf{M}$ & 36 & $\begin{array}{l}\text { Hypertension and } \\
\text { renal failure }\end{array}$ & $\begin{array}{l}\text { Interstitial } \\
\text { nephritis }\end{array}$ & $\mathrm{C}_{3}$ in vessels & +++ Droplets and crescentic staining \\
\hline 2 & $\mathbf{M}$ & 27 & $\begin{array}{l}\text { Adrenal cortical } \\
\text { adenoma }\end{array}$ & $\begin{array}{l}\text { Increased mesangial } \\
\text { matrix. } \\
\text { Tubules dilated. } \\
\text { Patchy inflammation }\end{array}$ & $\begin{array}{l}\text { Glomeruli show } \\
\mathrm{C}_{3} \text { trace }\end{array}$ & Trace \\
\hline 3 & $\mathbf{M}$ & 49 & $\begin{array}{l}\text { Septicaemia. } \\
\text { Renal transplant } \\
\text { (polycystic } \\
\text { kidneys) }\end{array}$ & $\begin{array}{l}\text { Mild membranous } \\
\text { changes. } \\
\text { Interstitial oedema } \\
\text { and fibrosis }\end{array}$ & $\begin{array}{l}\text { Glomeruli show } \\
\text { IgM }+++ \\
\mathbf{C}_{3}++\end{array}$ & Trace and occasional cap \\
\hline 4 & $\mathbf{M}$ & 20 & Nephrotic syndrome & $\begin{array}{l}\text { Proliferative exudative } \\
\text { glomerulonephritis. } \\
\text { Marked tubular } \\
\text { degeneration }\end{array}$ & $\begin{array}{l}\text { Glomeruli show } \\
\mathrm{C}_{\mathbf{3}}+ \\
\mathrm{C}_{\mathbf{4}}+ \\
\mathrm{C}_{\mathbf{1 q}}+ \\
\text { trace }\end{array}$ & + Occasional interlobular aggregates \\
\hline 5 & $\mathbf{M}$ & 29 & Lupus nephritis & $\begin{array}{l}\text { Diffuse endocapillary } \\
\text { lupus nephritis. } \\
\text { Tubular degeneration }\end{array}$ & $\begin{array}{l}\text { Glomeruli show } \\
\text { IgG }++++ \\
\text { IgA }++ \\
\mathbf{C}_{\mathbf{3}}+++ \\
\mathbf{C}_{\mathbf{1 9}}++++ \\
\mathbf{C}_{\mathbf{4}}+\end{array}$ & + Occasional aggregates \\
\hline 6 & $\mathrm{~F}$ & 41 & Papillary necrosis & $\begin{array}{l}\text { Segmental sclerosis. } \\
\text { Interstitial fibrosis and } \\
\text { tubular degeneration }\end{array}$ & $\begin{array}{l}\text { Glomeruli show } \\
\text { IgM trace } \\
\mathbf{C}_{\mathbf{2}}+ \\
\text { Vessels show } \\
\mathrm{C}_{\mathbf{8}}+\end{array}$ & ++ Aggregates \\
\hline 7 & $\mathbf{M}$ & 26 & $\begin{array}{l}\text { Acute graft } \\
\text { rejection } \\
\text { (Goodpasture's } \\
\text { syndrome) }\end{array}$ & $\begin{array}{l}\text { Acute rejection. } \\
\text { Patchy infarction }\end{array}$ & $\begin{array}{l}\text { Tubular basement } \\
\text { membranes show } \\
\text { linear } C_{3}+\end{array}$ & +++ Droplets and crescentic staining \\
\hline
\end{tabular}




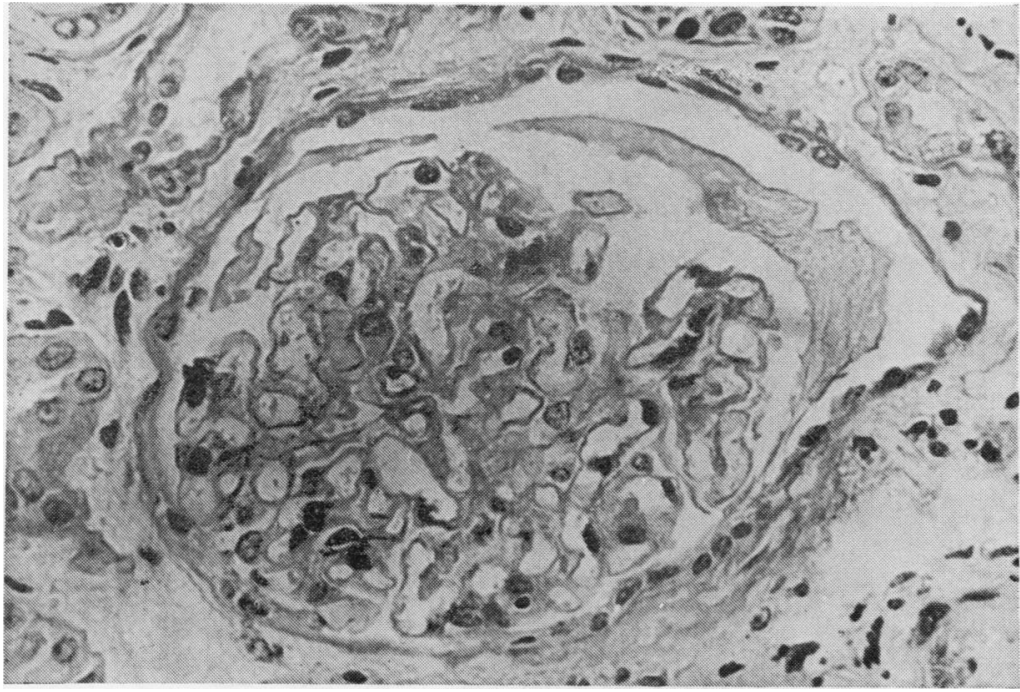

increased fibrous tissue together with some focal collections of chronic inflammatory cells. The primary renal lesion appeared to be an interstitial nephritis.

\section{IMMUNOFLUORESCENCE}

Most glomeruli showed collections of THP in the capsular space. In some glomeruli, aggregations appeared to be trapped between lobules of the glomerular tuft, and in others, a prominent crescentic collection in the capsular space capped the glomerulus (Fig. 4).

\section{Case 6}

A woman aged 41 years presented with hypertension and left ventricular failure and was shown by intravenous urography to have evidence of papillary necrosis.

\section{HISTOLOGY}

Glomeruli showed patchy segmental sclerosis with some peritubular fibrosis and collections of chronic inflammatory cells around damaged renal tubules. Vessels showed mild thickening.

\section{IMMUNOFLUORESCENCE}

Glomeruli showed occasional traces of IgM and some patchy $\mathrm{C}_{3}$, which was also present in small arteries. Small collections of THP were seen in the capsular space and between lobules of the glomeruli (Fig. 1).

\section{Case 7}

Fig. 5 Glomerulus showing irregular crescent of proteinaceous material in capsular space (case 1). Periodic acid Schiff $\times 420$
A man aged 26 years suffered from Goodpasture's syndrome, for which he had been treated by bilateral nephrectomy and plasmapheresis in 1975. In 1976 he received a renal transplant which failed and was removed in 1977. A further transplant, which was acutely rejected and removed after three weeks, is the subject of this report.

\section{HISTOLOGY}

The kidney showed well-defined areas of infarction of medulla and cortex, and adjacent areas showed evidence of acute rajection. Patchy collections of lymphoid cells were seen around peritubular vessels and tubules which appeared rather dilated (Fig. 6) and often contained casts. Interlobular arteries showed prominent intimal proliferation, almost leading to occlusion. Glomeruli showed a mild increase in mesangial matrix, and the capsular space often appeared dilated, sometimes with a prominent layer of lining cells.

\section{IMMUNOFLUORESCENCE}

Immunofluorescence revealed aggregations of THP in the capsular space in approximately $50 \%$ of glomeruli. This varied from a patchy irregular pattern where THP appeared to be trapped between glomerular loops (Fig. 2) to a capsular drop pattern, often becoming confluent, where aggregates adhered to the parietal epithelium lining the capsular space (Fig. 3), and more extensive crescentic aggregates 


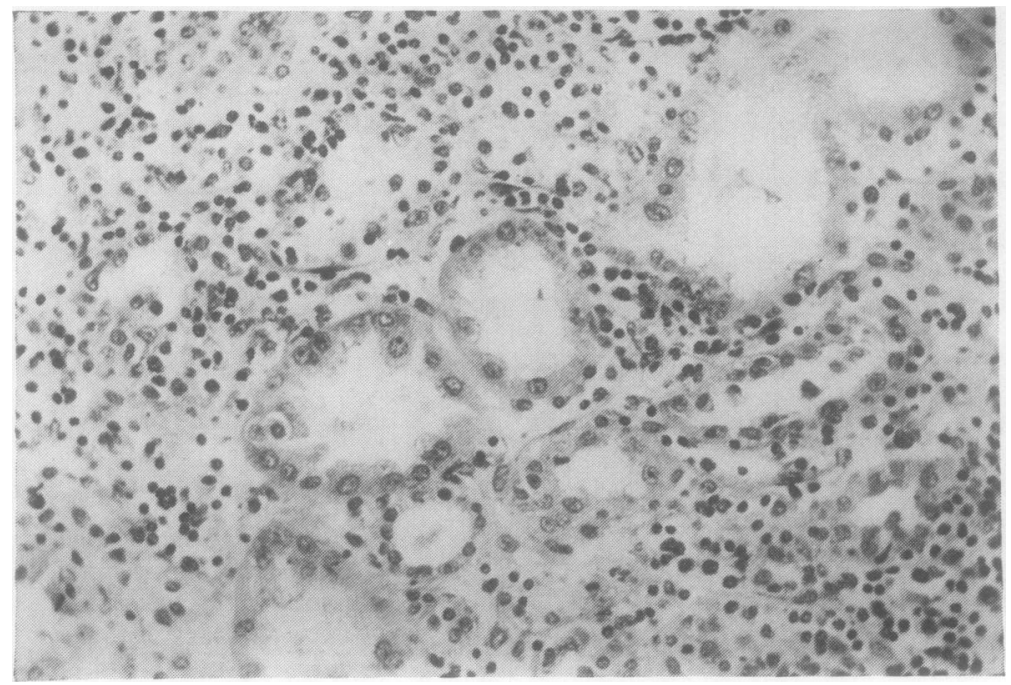

Fig. 6 Interstitial infiltrate of mononuclear cells around dilated tubules in kidney showing acute rejection (case 7). Haematoxylin and eosin $\times 210$

resembling those seen in case 1. Tubular casts stained strongly (Fig. 2).

\section{ELECTRON MICROSCOPY}

Material was observed in the capsular space, which was more electron dense than plasma seen in the lumen of capillary loops. At high magnification the granular material tended to be arranged in filaments and showed a periodicity of about $100 \AA$, resembling that seen in preparations of THP isolated from urinary casts, which show a periodicity of $110 \AA$ (Fletcher et al., 1970).

\section{Discussion}

Tamm-Horsfall protein has been studied extensively in normal renal tubular epithelial cells (McKenzie and McQueen, 1969; Schenk et al., 1971; Wallace and Nairn, 1971) and is recognised as being a significant component in tubular casts (McQueen, 1962). The present report appears to be the first demonstration of this urinary glycoprotein occurring in relation to the renal glomerulus and its capsule.

Normally, THP is demonstrated in the cytoplasm of the cells of the ascending limb of the loop of Henle and distal convoluted renal tubule, and, in our experience, when present in casts is usually seen in the collecting system, distal to the site of THP secretion, where the cytoplasm of the tubular cells embracing the casts does not stain for THP.

Theoretically, THP in the capsular space could result from filtration of a plasma component, secretion by a glomerular constituent such as mesangial cells, or perhaps from secretion by the parietal epithelial cells lining the capsular space, particularly when tubular epithelium has replaced the normal epithelial lining.

We cannot entirely exclude the possibility that THP entered the capsular space from the glomerulus. THP is not detectable in normal serum but it has been suggested that in reflux nephropathy THP may reach the circulation (Hodson et al., 1975). If it were derived from serum, THP might be expected to have a more widespread glomerular distribution.

Should THP be secreted by mesangial cells or cells lining the capsular space, we would have expected to detect its presence in these cells by immunofluorescence but have failed to do so.

A more likely explanation of our findings is the retrograde passage of THP from its site of production in the distal tubule, along the loop of Henle and proximal convoluted tubule into the capsular space

The patients reported above were in a series of 72 patients examined in a period of approximately one year. In each case only a proportion of glomeruli o were affected. However, each patient had histo- N pathological evidence of tubulo-interstitial damage, suggesting that there was an obstructive element in their renal condition.

There has been recent interest in the development of immunological reactions against THP in renal $\stackrel{\Phi}{\oplus}$ disease. Experimental studies in pigs (Hodson et al., 1975) suggested that reflux nephropathy led to the 0 formation of Tamm-Horsfall antibody, and Hanson et al. (1976) proposed that these antibodies might be useful in distinguishing between upper and lower $\varrho$ renal tract infections. Fasth et al. (1977) were unable to show a correlation between antibody titres and 8 
the presence of vesico-ureteric reflux or kidney scarring. Cell-mediated immunity against THP has been reported in patients with autoimmune liver disease associated with renal tubular acidosis (Tsantoulas et al., 1974). Antibodies and cellmediated immunity against Tamm-Horsfall protein were not studied in our cases. Indeed, the detection of cell-mediated activity against THP by lymphocyte blast cell transformation may prove difficult as we have found that some preparations of THP act as mitogens on lymphocytes from normal individuals.

The addition of Tamm-Horsfall antisera to the study of renal biopsies can provide useful evidence of the retrograde tubular passage of urine, which may be associated with tubulo-interstitial damage and intrarenal reflux and not be detectable by other methods of investigation.

We thank Dr K. L. Lynn for advice and the Department of Medical Illustration. This study was supported by a grant from the Medical Research Council of New Zealand.

\section{References}

Fasth, A., Hanson, L. A., and Asscher, A. W. (1977). Autoantibodies to Tamm-Horsfall protein in detection of vesicoureteric reflux and kidney scarring. Archives of Disease in Childhood, 52, 560-562.

Fletcher, A. P., McLaughlin, J. E., Ratcliffe, W. A., and Woods, D. A. (1970). The chemical composition and electron microscopic appearance of a protein derived from urinary casts. Biochimica and Biophysica Acta, 214, 299-308.
Hanson, L. A., Fasth, A., and Jodal, U. (1976). Autoantibodies to Tamm-Horsfall protein, a tool for diagnosing the level of urinary-tract infection. Lancet, 1, 226-228.

Hodson, J., Maling, T. M. J., McManamon, P. J., and Lewis, M. G. (1975). Reflux nephropathy. Kidney International, 8, Supplement, 50-58.

McGiven, A. R., Day, W. A., and Hunt, J. S. (1977). Glomerular lesions in argyric NZB/NZW mice. British Journal of Experimental Pathology, 58, 57-62.

McKenzie, J. K., and McQueen, E. G. (1969). Immunofluorescent localization of Tamm-Horsfall mucoprotein in human kidney. Journal of Clinical Pathology, 22, 334-339.

McQueen, E. G. (1962). The nature of urinary casts. Journal of Clinical Pathology, 15, 367-373.

Nairn, R. C. (1976). Fluorescent Protein Tracing, 4th edition. Churchill Livingstone, Edinburgh and London.

Schenk, E. A., Schwartz, R. H., and Lewis, R. A. (1971). Tamm-Horsfall mucoprotein. 1. Localization in the kidney. Laboratory Investigation, 25, 92-95.

Tsantoulas, D. C., McFarlane, I. G., Portmann, B., Eddleston, A. L. W. F., and Williams, R. (1974). Cellmediated immunity to human Tamm-Horsfall glycoprotein in autoimmune liver disease with renal tubular acidosis. British Medical Journal, 4, 491-494.

Wallace, A. C., and Nairn, R. C. (1971). Tamm-Horsfall protein in kidneys of human embryos and foreign species. Pathology, 3, 303-310.

Requests for reprints to: Professor A. R. McGiven, Department of Pathology, The Christchurch Clinical School, Christchurch Hospital, Christchurch, New Zealand. 